\title{
Obituary
}

\section{Air Vice-Marshal Wilfrid Oulton}

Air Vice-Marshal Wilfrid Oulton, who died on 3 i October i 997, aged 86, was one of that select group of distinguished Royal Air Force pilots who became equally distinguished navigators. Much of his early Service experience in World War II was spent in Coastal Command, where his natural flying ability combined with his acquired navigator's knowledge and skill led to exceptional operational achievements.

In I 943, German submarines were taking a devastating toll of Allied shipping in the North Atlantic and Wilf Oulton was flying long-range patrols over the Bay of Biscay. In May of that year, commanding a Halifax bomber which had been converted for maritime operations, he attacked with depth charges and sank two U-boats and shared in the destruction of a third. For these outstanding successes, which helped mark the Battle of the Atlantic turning in our favour, he was awarded the DSO.

Later, and completely different, with the cessation of hostilities, Oulton was jointly responsible for the introduction of the first Air Traffic Control system at Heathrow. And, different again, his ability to inspire confidence and co-operate extremely well with others led to the most challenging peace-time appointment as Joint Task Force Commander of 'Operation Grapple', which supported the British hydrogen bomb tests at Christmas Island in the Pacific Ocean.

Following retirement from the RAF in I960, he joined the electronics industry and for the next decade was an active member of the Royal Institute of Navigation.

Wilfrid Ewart Oulton was born on 27 July г 9 г I, and educated at Abertillery, from whence he won a scholarship to University College, Cardiff. In 1929 , he passed into the RAF College at Cranwell as a prize cadet with exceptional marks.

He was commissioned in I 93 I and joined a flying boat squadron in Malta as a pilot officer. He returned home in 1935 to attend the Air Navigation Course at Manston, where he was swiftly recognised as an outstanding navigator with instructor potential. He developed a great interest in all aspects of navigation which continued throughout his life. On his return to Coastal Command, his expert navigation skills were highly valued because the navigation aids in use at the time were somewhat primitive and rudimentary.

With the outbreak of war in 1939, Oulton saw operational duty with an Anson programme flying shipping and anti-submarine patrols over the Western approaches to the Channel, but was later selected for a special posting to Washington to advise on the navigation training to be given to the British and Commonwealth aircrew at flying schools in America.

On his return to the UK, he continued maritime patrols, commanding a Halifax squadron with exceptional success, as described earlier, and even a Flying Fortress squadron from a base in the Azores where, on one occasion, he enjoyed the privilege of entertaining General Eisenhower. In 1945 he was posted to Northern Ireland as Deputy Director, Maritime Operations, Ireland.

His extensive North Atlantic experience and knowledge of air navigation led next to a special Air Ministry post tasked to assist with the development of the Air Traffic Control systems, navigation aids and procedures required for the safe growth of civil 
aviation for London's new airport at Heathrow. In 1946 he returned to Northern Ireland as RAF Director of the Joint Anti-Submarine School at Londonderry.

For his many wartime achievements Oulton was mentioned in despatches in 1940, 1 943 and again in 1945, and in 1943 was awarded both the DSO and the DFC.

Early in his career Oulton had studied languages and in $195^{\circ}$ he was appointed Air Attaché to Argentina, Uruguay and Paraguay, returning in 1954 to the Air Ministry as a Director of Operations. It was here in 1956 that he was astonished to be informed that he was to take command of 'Operational Grapple', the Joint Task Force charged with the planning and execution of the Christmas Island tests on the British hydrogen bomb. He started from scratch on this mammoth task, and eventually mobilised a combined force of some 4000 men and women, which efficiently moved thousands of tons of weapon equipment, instruments and supplies to the other side of the globe. It was a tremendous achievement calling upon a high level of management, professional knowledge, organisational ability and qualities of leadership. His final service appointment was as Senior Air Staff Officer at RAF Coastal Command, from which he retired at his own request in 1960 .

As a civilian, Oulton was soon busy in the defence electronics industry, joining the board of EMI Electronics with a broad oversight of the company's military programmes and the links forged with their partner, Hughes, in California. He also now had time to pursue more directly his early attraction to navigation matters and from 1962 to 1965 was a keen and active member of the RIN Council. He was elected a Fellow of the RIN in 1964 and a Vice-President in I 965 , and over this period made major contributions to all affairs of the Institute, whether technical, administrative or financial. However, the increased demands of his various business activities, extensive overseas travel and a growing interest in writing led, understandably, by the end of the decade to reduced Institute attention.

Oulton was a Fellow of the Institute of Electrical Engineers and an Honorary Fellow of the University of Wales, and as well as his many decorations for wartime gallantry and dedication to duty, he was awarded the CBE in 1953 and the CB in 1958 .

His easy, pleasant, courteous manner deceptively masked the confidence, inner determination and toughness which served him so well throughout a most distinguished military and civilian career. He was a keen sportsman, an RAF squash champion in his younger days and still playing in later life. It was at this time that he published two books Christmas Island Cracker (1987) and more recently Technocrat (1995).

He married Sarah Davies in 1935 and they had three sons. She died in 1990 and he married Letitia Malcolm, who survives him. 